\title{
RED FOX-COMMON RAVEN INTERACTION
}

\section{ROBERT W. NERO, Box 1495 St. James St., Winnipeg, Manitoba R3H OW9}

I saw Red Foxes on every outing I made last winter (1992-93) in southern Manitoba. Usually, we see them only briefly, as we drive past in search of owls of one kind or another. On 7 February 1993, however, I watched one from 2:00 to 2:30 p.m. on the Maple Creek Road, close to Brightstone Sand Hills Provincial Forest, approximately $10 \mathrm{~km}$ northwest of Lac du Bonnet. Herb Copland and I had just banded and released a Great Gray Owl; it flew back to its perch on a tree stub not far from the road on the edge of a broad snow-covered field. We decided to park for lunch while watching the owl and keeping an eye out for a second one that had moved away during the banding operation. It was windy and the clouds were breaking, so it was fairly bright.

The fox appeared on my side of the car and perhaps $150 \mathrm{~m}$ away at the far end of the field, adjacent to a distant woods. Even without binoculars I could see its general movements, so I kept eating and glancing at the fox. It moved around slowly and seemed to be sniffing the ground as if hunting for mice. Given that the snow was more than 0.6 $\mathrm{m}$ (2 feet) deep, with a crust that in places supported our weight (as we learned when we went after the owl), I wondered how successful the fox would be. Once, it dug energetically in the snow, working first with its forefeet, then kicking the snow backwards with its hind feet. It was so far away, however, that I could not see if it found anything. After about 10 minutes, a raven arrived; from high overhead it dived down to land about $50 \mathrm{~m}$ from the fox. After probing the snow with its beak, the raven flew towards the fox, landed within a few metres, then walked around the fox at close range and stood nearby. At this time, the raven's feathers were fluffed out, making it look larger that the fox, as I pointed out to Herb, who agreed. The raven flew off, landed again about $50 \mathrm{~m}$ away and searched about on the snow. This performance was repeated three times.

By now I had had the fox and the raven in sight for 20 minutes. All this while I alternated between looking at the fox and the Great Grey Owl which sat atop the stub, facing the sun and us, with its back to the wind. The fox was now lying down on the snow with its head up, apparently resting. When the raven flew to the fox for the fourth time, it landed about $3 \mathrm{~m}$ in front of it, then rapidly walked directly up to it and, to my surprise, reached out with its beak to the fox's mouth, or at least to its nose. As this was happening, the fox remained lying down, head up, seemingly completely amenable to the raven's close contact. After this astonishing event, the raven stepped back, walked off to one side, then flew away to the south and out of my sight. As far as we could see, there was only one raven involved, although there were other ravens down the road. Presumably the one we were watching flew down to join the others. Not very long after this, the fox abruptly stood up as if alarmed, looking in the direction the raven had flown. Then it turned and trotted rapidly away into the woods.

I excitedly described all this for Herb's benefit, but I was at a loss for an explanation. The least that we could judge, given the considerable distance at which the observation was made, was that there seemed to be a curiously friendly relationship between the fox and the raven, a sense of trust and familiarity that surprised us both. 
In a recent book on the Common Raven, Bernd Heinrich notes that "ravens associate with any animals that kill large game" and that "carnivores are reported to be remarkably tolerant of ravens." Wolves, sled dogs, even wolverines are mentioned as paying little attention to ravens attracted to their kills, though Heinrich points out that the "99.5 percent of the time that the wolf is tolerant hardly matters." He goes on to suggest that a raven risks "danger by approaching meat of any kind," for carnivores, including foxes, may still be in the vicinity. ${ }^{1}$

But hunger, says Heinrich, is not the only reason ravens approach carnivores. Ravens that repeatedly sneaked up behind a fox and a Bald Eagle at carcasses set out for bait by photographers in Ontario, for example, were judged by those observers to be doing so out of "desire to impress one's fellow ravens with one's daring. Perhaps these are males doing their chivalrous bit for the females." Heinrich examined filmstrips of these observations and found that the ravens involved were "strutting and feather posturing, doing the classical raven dominance display of courting males." He concluded that the ravens approaching carnivores are demonstrating their suitability as mates by bringing potential suitors to a carcass "to show her that he (and hence she as well) can feed at it. But carcasses are rare; there is not always opportunity for such a demonstration. So the male shows his mettle on substitutes. The bird who approaches a lone wolf will surely dare to approach a carcass."1 Our raven, which certainly had its feathers raised, may thus have been demonstrating its prowess for a distant, watching mate.

Another possible explanation for our observation may be found in David Henry's masterful book on the Red Fox. ${ }^{2}$ Foxes regularly cache food, then return later to dig it up when needed. A long list of scavengers, including ravens, are known to take food from fox caches. Henry notes that corvids will follow a fox carrying food, sometimes for a considerable distance, watch the fox make a cache, then after the fox has moved off, attempt to uncover it. The digging action which I saw our fox do may have been an effort to uncover a cache so that it could feed. When it lay down, it may have been protecting the cache from the raven.

1. HEINRICH, B. 1989. Ravens in winter. Summit Books, Toronto. 379 pp.

2. HENRY, J.D. 1986. Red Fox, the catlike canine. Smithsonian Institution Press, Washington, D.C. 174 pp.

\section{RAVEN PREDATION}

On the afternoon of 11 February 1993, I noticed a flock of Common Ravens fly by my seventh-floor office window. As the ravens were not doing their usual aerobatics in the thermal air currents over the office tower, I took a second look. This is when I noticed a Rock Dove being chased and harassed by the ravens. As they flew by beneath my level it was easy to watch what was happening. One raven pecked at and eventually grabbed and held the head of the pigeon. After being released the pigeon appeared injured. It descended, glided and landed on the north side of the river. All seven ravens landed there as well. As I did not see the Rock Dove fly away or the ravens leave the area, I presumed the Rock Dove was killed.

Carmen Dodge, Box 285, Prince Albert, Saskatchewan. S6V 5R5 